status as has been accorded to the Scottish Division in its relationships with the Scottish Home and Health Department and the Scottish Royal Colleges. Already there are signs of improvement, and recently the President attended the Annual Meeting and Dinner of the Division in Dublin and was able to report some of these developments and to assure the Division of our concern. We all look forward to the Quarterly Meeting in Dublin next spring.

At the Sixth World Congress of Psychiatry organized under the auspices of the World Psychiatric Association the amendment to the College's resolution on Dissenters put by the Royal Australian and New Zealand College of Psychiatrists was passed by a narrow majority. Following the Hawaii meeting the Declaration of Hawaii has been published and member societies of the WPA are being invited to comment upon, contribute towards, and make nominations for two committees, one to review the abuse of psychiatry and the other on ethics.

Also during the Hawaii Meeting this College held a Reception for its members from Britain and overseas who were attending the Congress in order to bring our members together, to discuss the College Appeal and ways in which members living abroad can be involved in this and other College activities. It was by all reports a very happy and successful occasion.

I am very pleased to report that at the recent meeting of Council an application from the Group for the Psychiatry of Old Age to become a Specialist Section was supported and approved for submission to the next Annual General Meeting.
Finally, I wish to express on behalf of the College, and especially on behalf of all of us who have attended this memorable meeting, our thanks to those whose hard work and generosity has made it possible. To our hosts on Sunday night, especially the District Management Team, at 'The York Lunatic Asylum' we are most grateful for the splendid Reception, and the Museum authorities and the University for the arrangements for our papers and lunches. For the Dinner last night in such a magnificent setting we are truly grateful to the Governor of the Merchant Adventurers' Company. To Dr Bowen who has done so much to make it all possible and for his learned and fascinating paper yesterday, and to all his helpers, we give our thanks and congratulate Bootham Park Hospital on its Bicentenary.

\section{Social Functions}

The Reception on the evening of Sunday, 13 November, offered to the College by the Hospital and the District Management Team, attracted a large attendance of members and their wives, and a most enjoyable and memorable time was spent in these historic surroundings.

On 14 November Members and guests attended a Dinner at the Merchant Adventurers' Hall.

The President and Mrs Rees entertained the Maudsley Lecturer, Professor Kathleen Jones, and Officers of the College, to lunch on Tuesday, 15 November.

\title{
OUR PRESIDENT HONOURED
}

We offer our warmest congratulations to the President of our College, Professor W. Linford Rees, who was awarded a C.B.E. in the New Year Honours List. 